\title{
Breeding Low-Cadmium Wheat: Progress and Perspectives
}

\author{
Imdad Ullah Zaid ${ }^{1}$, Xin Zheng ${ }^{1}$ and Xiaofang $\mathrm{Li}^{1,2, * \mathbb{C}}$ \\ 1 Key Laboratory of Agricultural Water Resources, Centre for Agricultural Resources Research, Institute of \\ Genetics and Developmental Biology, Chinese Academy of Sciences, No. 286 Huaizhong Rd, Shijiazhuang \\ 050021,China; imdadcas@gmail.com (I.U.Z.); zhengxin@sjziam.ac.cn (X.Z.) \\ 2 CMLR, Sustainable Minerals Institute, The University of Queensland, Brisbane, Queensland 4072, Australia \\ * Correspondence: xfli@sjziam.ac.cn or x.li10@uq.edu.au; Tel.: +86-311-85822874; Fax: +86-311-85815093
}

Received: 26 September 2018; Accepted: 31 October 2018; Published: 3 November 2018

\begin{abstract}
Farmland cadmium (Cd) contamination has adverse impacts on both wheat grain yield and people's well-being through food consumption. Safe farming using low-Cd cultivars has been proposed as a promising approach to address the farmland $\mathrm{Cd}$ pollution problem. To date, several dozen low-Cd wheat cultivars have been screened worldwide based on a $\mathrm{Cd}$ inhibition test, representing candidates for wheat $\mathrm{Cd}$ minimization. Unfortunately, the breeding of low-Cd wheat cultivars with desired traits or enhanced $\mathrm{Cd}$ exclusion has not been extensively explored. Moreover, the wheat $\mathrm{Cd}$ inhibition test for variety screening and conventional breeding is expensive and time-consuming. As an alternative, low-Cd wheat cultivars that were developed with molecular genetics and breeding approaches can be promising, typically by the association of marker-assisted selection (MAS) with conventional breeding practices. In this review, we provide a synthetics view of the background and knowledge basis for the breeding of low-Cd wheat cultivars.
\end{abstract}

Keywords: cadmium; farmland; wheat; cadmium resistance; breeding methods

\section{Introduction}

Cadmium (Cd), being a non-essential element, is among the most toxic metals [1]. $\mathrm{Cd}$ and Cd-bearing minerals have been widely used in modern industries and agriculture. Globally, metal industries produce 24,000 tons of Cd each year, with China being the top producer [1]. Meanwhile, worldwide, $17.5 \mathrm{Tg}$ of Cd-bearing phosphate fertilizers are applied annually in recent years, about $50 \%$ of which are applied in China, the United States (US), and India [2]. Surveys showed that European phosphate fertilizers contain $7.4 \mathrm{mg} / \mathrm{kg} \mathrm{Cd}$ on average [3], which is around 20-fold higher than the $\mathrm{Cd}$ geological background. Phosphate fertilizers that are produced in the US contain considerable amounts of $\mathrm{Cd}$ as well $(4-109 \mathrm{mg} / \mathrm{kg})$ [4]. Globally, the increasing use of phosphate fertilizers since the 1960s has inevitably caused widespread farmland Cd pollution. Wastewater irrigation and dry deposition have also created hotspots of Cd-polluted land [5]. As a result, farmland $\mathrm{Cd}$ pollution has been a major concern for decades in many industrialized and developing countries. For example, about $9.5 \%$ of Japanese paddy soil is more or less polluted by $\mathrm{Cd}$. In China, official reports showed that $7 \%$ of China's farmland is Cd-contaminated.

Farmland Cd pollution poses considerable risks to human health through the consumption of foods with excess Cd, particularly staple foods. Wheat (Triticum aestivum L.) is a staple food crop for nearly $35 \%$ of the world population [6]. Since 1991, China has been one of the top wheat producers in the world. In the year 2016, China produced 128 million metric tons of wheat on its 24 million hectares of farmland. Nonetheless, wheat Cd contamination has inevitably been a hot topic in China as a result of farmland pollution. In Dakuai Town of Xinxiang, Henan, China, at least 150,000 kg of wheat with Cd 
levels 1.7-12.8-fold higher than the national food standards is produced each year. More "Cd wheat" can be found in the vicinity of many industrial gathering areas in Xinxiang. In 2016, about 666 ha of wheat field in the Muye District of Xinxiang was changed to a plantation of garden plants and flowers due to heavy metal contamination. Moreover, "Cd wheat" has also been detected in some wastewater irrigation areas of Shijiazhuang [7], Kaifeng [8], Beijing [9], and Tianjin [10]. The identified, as well as more unidentified, wheat $\mathrm{Cd}$ contamination has posed a considerable health risk to people, particularly the local people. Long-term exposure to $\mathrm{Cd}$, even at a low rate, will cause bone diseases, emphysema, and proteinuri [11]. Therefore, minimizing food heavy metal pollution, including wheat Cd contamination, is now a priority task in the "Prevention and Control of Soil Pollution Action Plan" released by the Chinese government on 28 May 2016.

Safe farming of the polluted farmland, which aims to produce metal-safe crops without purposefully removing soil heavy metals, is thought to be one of the best strategies. Safe farming in Cd-polluted farmland has involved several biomaterials and agronomic measures, and low-Cd cultivars are recognized as an economic and sustainable one. Low-Cd wheat cultivars are supposed to be effective and essential in the polluted farmland of wheat-maize rotation areas, typically in the Yellow River and Huai River Valleys of China. The screening of low-Cd cultivars was started decades ago [12], though it was not proposed as a formal measure for heavy metal pollution control until 2006 [13]. Since then, many studies have been purposefully dedicated to the screening of low-Cd cultivars, most of which are wheat and rice cultivars. There have also been several excellent reviews on the selection of low-Cd (Cd-safe) cultivars [14,15]. In this review, we focus on the exploration of possible schemes of low-Cd cultivars breeding, based on a synthetic view of the phenotypic and genotypic responses of wheat to $\mathrm{Cd}$ and the available breeding strategies.

\section{Cd Effects on Wheat Growth and Development}

In general, the presence of more than $5-10 \mathrm{mg} / \mathrm{kg}$ of $\mathrm{Cd}$ in agricultural soil has adverse effects on crop cultivations [16]. The $\mathrm{Cd}$ toxicity symptoms that were observed in crops may arise due to the wide range of interactions at the cellular level. A huge number of studies have reported the impacts of excess Cd uptake on crops metabolism and physiological processes [17-22].

In wheat, $\mathrm{Cd}$ stress has induced several biochemical disorders of the cell membrane, lipid and protein synthesis, and nutrient metabolism, as well as decreases in the chlorophyll content [23-25]. Wheat exposed to high levels of Cd shows visible symptoms of chlorosis, necrosis, spotting of roots, and a reduction in leaf number and leaf area $[26,27]$. In wheat, root epidermis is the primary acting site of $\mathrm{Cd}$ toxicity, where roots significantly accumulate more $\mathrm{Cd}$ than other plant parts [28,29]. $\mathrm{Cd}$ had intensive effects on root growth and elongation, normally decreasing the root/top ratio. $\mathrm{Cd}$ induces several oxidative signals at root membrane sites that elicit programmed cell death (PCD). Wheat photosynthetic pigments are also sensitive to $\mathrm{Cd}$ stress, especially the structure and function of chloroplasts [30].

Soil Cd contamination has a substantial impact on the quantitative traits of wheat plants. Rebekic and Loncaric [31] evaluated 51 winter wheat cultivars under $20 \mathrm{mg} \mathrm{Cd} \mathrm{kg}^{-1}$ soil for yield and yield-related traits. Their results showed that high soil $\mathrm{Cd}$ concentrations caused a significant reduction in wheat seed weight per spike by $27 \%$, followed by reductions in kernel weight and seed number per spike by $5.2 \%$ and $23 \%$, respectively. Similarly, Ci and his colleagues (2009) evaluated four wheat cultivars under $0.050 \mathrm{M}$ of $\mathrm{Cd}$ concentration for morphological characteristics. They found a visible decrement in most of the growth and root parameters under $\mathrm{Cd}$ toxicity [32]. In roots, Cd competes for absorption with other mineral nutrients sharing similar chemical properties with $\mathrm{Cd}$, such as $\mathrm{Ca}^{2+}$ and $\mathrm{Mg}^{2+}$, causing a mineral deficiency in plants. The available evidence showed that $\mathrm{Cd}$ treatment reduced the amount of nitrate salts and sugar concentrations, while it amplified the free amino acid concentrations in wheat roots and shoots [32,33]. 


\section{Molecular Mechanisms of Cd Resistance in Wheat}

Unlike rice, wheat (a hexaploid) has not been extensively explored regarding its genetic determinants for $\mathrm{Cd}$ tolerance. In this section, we reviewed the identified genes and molecules that are involved in wheat antioxidation processes, metal sequestration, exclusion, signaling pathways, and transcriptional regulation (Figure 1).

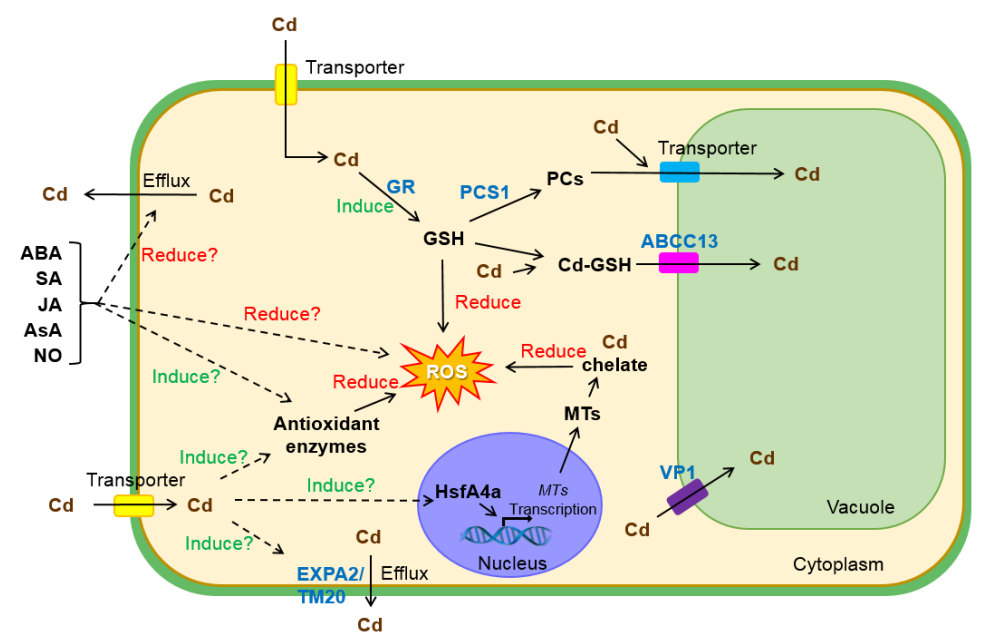

Figure 1. A diagram explaining the molecular mechanisms of cadmium $(\mathrm{Cd})$ resistance in wheat. ABA, abscisic acid; SA, salicylic acid; JA, jasmonic acid; AsA, ascorbic acid; NO, nitric oxide. ROS, reactive oxygen species; GR, glutathione reductase; GSH, reduced glutathione; PCs, phytochelatins; PCS1, PC synthase 1; MTs, metallothioneins. ABCC13, ATP binding cassette subfamily C member 13.

\subsection{Antioxidation and Sequestration}

$\mathrm{Cd}$ can inhibit the antioxidant defense system of plants and induce the formation of reactive oxygen species (ROS), which could cause oxidative stress [34-36]. As a conservation strategy, plants accumulate a variety of antioxidant products, such as reduced glutathiones (GSHs), to protect functional proteins from oxidative damages. In wheat, chronic $\mathrm{Cd}$ exposure increased the activity of glutathione reductase (GR), a key enzyme maintaining the content of GSH [37]. Induction of distinctive isoforms of GR has been observed in wheat, indicating a GR-associated defense mechanism against Cd stress [37].

Heavy metal-GSH conjugates can be transported into vacuoles by ABCC (ATP binding cassette subfamily C) transporters [38-40]. Heterologous expression of TaABCC13 conferred tolerance to heavy metals by the utilization of GSH, which was in accordance with the fact that the silencing of TaABCC13 leads to sensitivity to $\mathrm{Cd}$ in transgenic wheat [41]. TaABCC13, also called TaMRP3, enhanced the $\mathrm{Cd}$ tolerance of yeast ycf1 mutant through the GSH-mediated detoxification pathway [42,43]. GSH is also the precursor of many phytochelatins (PCs), synthesized by PC synthase (PCS) [44,45].

Heavy-metal-complexing PCs could decrease Cd content in eukaryotic cells by $\mathrm{Cd}$ sequestration and thus ameliorate Cd-induced oxidative stress [46,47]. Arabidopsis alcohol dehydrogenase (Adh) promoter-driven TaPCS1 expression caused a specific root expression of TaPCS1 in cad1-3 (an AtPCS1 loss-of-function mutant) [48]. Adh::TaPCS1/cad1-3 complemented the Cd sensitivities of the cad1-3 and showed induced $\mathrm{Cd}^{2+}$ and PC content in Arabidopsis shoots [48], indicating an enhanced Cd tolerance function. However, contradictory results were also observed when PCS was overexpressed in Arabidopsis and tobacco [49-51]. Wang et al. [52] reported that the heteroexpression of TaPCS1 in rice reduced $\mathrm{Cd}$ tolerance and increased $\mathrm{Cd}$ accumulation and PC content in shoots. GSH reduction might result in Cd sensitivity, yet more evidence is required to clarify the function of a single PCS gene in response to $\mathrm{Cd}$ stress.

Another reported sequestration-related protein in wheat is TaVP1, a vacuolar $\mathrm{H}^{+}$-pyrophosphatase (V-H-PPase). TaVP1 was first cloned by Brini et al. [53], and its function in Cd tolerance was evaluated 
by being ectopically expressed into tobacco [54]. The transgenic lines showed enhanced Cd tolerance, higher $\mathrm{Cd}$ accumulation, and higher CAT activity when compared with the wild type [54].

\subsection{Exclusion}

The ability to preclude or reduce root $\mathrm{Cd}$ uptake is a key resistance mechanism in plants. To date, little is known about Cd exclusion-related genes in wheat. Kim et al. [55] reported a wheat transmembrane protein, encoded by TaTM20, which conferred $\mathrm{Cd}$ tolerance when expressed in yeast cells. The expression of TaTM20 induced Cd efflux, which caused lower Cd content in yeast cells, even under the condition of reduced GSH content.

\subsection{Phytohormone and Signal Molecule Regulation}

A number of studies showed that plant hormones and signal molecules were involved in plant Cd response, such as salicylic acid (SA), abscisic acid (ABA), jasmonic acid (JA), ascorbic acid (AsA), and nitric oxide (NO) [56]. Exogenous AsA treatment significantly increased $\mathrm{NO}$ and endogenous AsA contents, inhibited ROS accumulation and $\mathrm{Cd}$ absorption, and enhanced the $\mathrm{Cd}$ tolerance of wheat seedlings [57]. NO is a well-known secondary messenger that regulates plant response to abiotic stress. Evidence was also shown that exogenous NO induced Cd resistance in wheat seedlings [57]. Similarly, results have also indicated the protective role of exogenous SA against $\mathrm{Cd}$ stress in maize and barley [58,59]. Kovács et al. reported that Cd induced SA synthesis in wheat, and wheat genotypes with different levels of tolerance exhibited various SA contents in accordance with GSH metabolism, indicating a role of SA-related signaling in Cd tolerance in wheat [60].

\subsection{Transcriptional Regulation}

Transcriptional factors (TFs) play important roles in regulating Cd detoxification-related genes in plants. A number of studies demonstrated that some Cd response TFs, such as AtbHLH29/38/39 [61], BnbZIP2 [62], ZAT6 [63], and PvERF15 [64], enhanced plant Cd tolerance transcriptionally. Shim et al. reported that TaHsfA4a, a class a4 heat shock transcription factor from wheat, conferred Cd resistance in both yeast and rice [65]. The knockdown of OsHsfA4a, which is a homolog of TaHsfA4a, decreased $\mathrm{Cd}$ resistance in transgenic rice [65]. Further functional analysis showed that the DNA binding domain (DBD) of TaHsfA4a was crucial for Cd tolerance. Moreover, TaHsfA4a-mediated Cd tolerance in yeast cells was found to be metallothionein (MT) gene-dependent, suggesting that TaHsfA4a might confer $\mathrm{Cd}$ tolerance by upregulating the expression of MTs in wheat [65].

\subsection{Other Mechanisms}

Recently, Dobrikova et al. [66] reported a wheat Rht-B1c mutant that showed enhanced Cd tolerance under $100 \mu \mathrm{M} \mathrm{Cd}$ treatment. The mutant expressing aberrant DELLA proteins showed limited gibberellic acid (GA) responsiveness, which caused growth repression [67].

Ren et al. reported a wheat expansin gene, TaEXPA2, which was upregulated in leaves when subjected to Cd stress [68]. Expansins are cell wall-located proteins that regulate plant development and response to various abiotic stresses [69-72]. Under Cd stress, TaEXPA2 conferred improved germination rate, root elongation, biomass accumulation, and photosynthesis when overexpressed in tobacco. The transgenic lines exhibited an efficient efflux of $\mathrm{Cd}$, lower $\mathrm{Cd}$ accumulation, and enhanced antioxidant enzyme activities in comparison with the wild type [68]. These results suggested that TaEXPA2 may regulate plant $\mathrm{Cd}$ tolerance, probably through the activation of $\mathrm{Cd}$ efflux and antioxidation.

$\mathrm{P}_{1 \mathrm{~B}}$-ATPases, also called heavy metal ATPases (HMAs), play direct roles in plant heavy metal transmembrane transport. Tan et al. reported that TaHMA2 was involved in the long-distance transport of $\mathrm{Zn} / \mathrm{Cd}$ in transgenic rice [73]. TaHMA2 conferred transgenic yeast cells a better $\mathrm{Cd}$ tolerance. The overexpression of TaHMA2 in rice increased the root-to-shoot transport of $\mathrm{Cd}$, and the transgenic rice showed better $\mathrm{Cd}$ resistance under low $\mathrm{Cd}$ treatment [73]. 


\section{Breeding Strategies for Low-Cd Wheat Cultivars}

Low-Cd wheat cultivars are the most effective, viable, and economic mean to reduce $\mathrm{Cd}$ health risks that are related to food consumption. Enhancement of wheat $\mathrm{Cd}$-stress and reduction in grain $\mathrm{Cd}$ uptake can be realized by both conventional and modern breeding methods. In conventional breeding, low-Cd wheat cultivars are selected based on the measurements of morphological, physiological, or biochemical parameters that are associated with $\mathrm{Cd}$ stress. To improve the genetic background of wheat cultivars with enhanced Cd resistance, intra-specific crosses among superior individuals are usually developed, followed by selection in succeeding generations. To handle segregating materials, breeding methods, such as mass selection, pure line, and recurrent selection methods can be effectively used in the development of low-Cd wheat cultivars. However, the tolerance established in crops with conventional methods is usually not very robust or broad-spectrum [74]. Conventional selections are dependent upon several environmental variations and thus require a widespread location/generation field trial, delaying the progress of cultivar development [75]. As a general breeding criterion, 8-10 years of substantial breeding efforts are required to breed a cultivar right from the pre-breeding phase up to commercial release [76]. Modern breeding practices that create genetic difference along with enhancements in screening and selection compensate to a large extent for conventional breeding.

The recent advancements in molecular genetics knowledge have established many modern breeding methods to confer $\mathrm{Cd}$ resistance in wheat. Progress in wheat against $\mathrm{Cd}$ stress continues by exploiting molecular breeding tools, such as marker-assisted selection, allele discovery, allele pyramiding, genome mutation, association mapping, genome selection, and next-generation sequencing [77]. Currently, there are two key molecular approaches to assess $\mathrm{Cd}$ stress in wheat: marker-assisted selection and genomic selection [78]. Molecular markers have been widely used in bi-parental mapping and genome-wide association (GWA) studies to underline and characterize candidate genes and favorable alleles that are associated with Cd stress in wheat [79]. On the functional basis, the associated markers have a breeding value that is based on the association of phenotype and marker genotype. The summation of all breeding values has potential impact in the selection process of low-Cd cultivars. Yet, as these breeding methods are becoming progressively fast and accurate, plant breeders favor them for decreasing the environmental pressure on breeder selections. The adoption of molecular breeding methods and their successful integration with conventional breeding methods will have potential impact on the development of low-Cd wheat germplasm.

\subsection{Genetic Variation and Selection of Low-Cd Wheat Cultivars-Conventional Breeding Approaches}

Conventional breeding has been successfully utilized and considerable breeding progresses/genetic gain has been achieved in many traits, such as yield, quality, and stress ability. Practicing conventional methods for adaptation to abiotic stresses is challenging, as compared to breeding for other plant characters. For each of the abiotic stresses there are different mechanisms of resistance, which can be contrary, depending on the plant stress-adaptive nature [80]. However, conventional breeding methods have certain limitations and drawbacks, and thus little achievement has been gained so far in the breeding of wheat for abiotic stresses, especially $\mathrm{Cd}$ stress. Plant breeders generally practice conventional breeding methods, i.e., introduction, selection, and hybridization in favor of the development of low-Cd wheat cultivars. As a result, several low-Cd wheat cultivars were imperatively developed through conventional breeding approaches. For example, Yue et al. (2018) evaluated three wheat cultivars-Sumai 3, Jingdong 8 (JD 8), and Nannong 9918-under four different Cd levels [81]. Their results listed JD 8 as a Cd-tolerant cultivate, containing the lowest Cd content and relatively less toxicity as compared to Sumai 3 and Nannong 9918 cultivars. Similarly, 15 wheat cultivars were tested under $\mathrm{Cd}$ concentrations of 15,30 , and $45 \mu \mathrm{M}$. The results revealed that Lasani-2008 and Iqbal-2000 exhibited the lowest Cd contents, while Sehar-2006 and Inqlab-91 exhibited the highest Cd concentration in shoots [82]. Moreover, a large number of conventional studies were performed to screen out Cd-safe wheat cultivars (Table 1). 
Breeding for the low-Cd trait requires reliable knowledge of natural variation among the given population, pedigree information of cultivars, and future breeding strategies for developing and pyramiding low-Cd traits with other quantitative traits [14]. Wheat species and cultivars vary extensively in their ability to grip, accumulate, and tolerate $\mathrm{Cd}$ [83]. The available literature showed significant variations in $\mathrm{Cd}$ tolerance between wheat species, both in bread wheat and durum wheat [12]. However, its concentration in hexaploid bread wheat is less characterized [84]. This inter-varietal variation may evolve due to differences among cultivars in Cd adsorption or uptake or agents of internal transport systems or due to the retention of $\mathrm{Cd}$ in different vascular tissues [85]. Furthermore, differences in $\mathrm{Cd}$ accumulation may also depend on the adaptation of different genotypes to environmental and production conditions [86].

In conventional breeding practices, genetic variation is created through planned or random cross combinations of genotypes. The presence of valuable genetic resources leads to the exploitation of heterotic performances evolved by the interaction of gene actions. In wheat, low-Cd cultivars are often developed by the hybridization of parental lines possessing $\mathrm{Cd}$ resistance ability. It has been reported that hybrid wheat showed a $10 \%$ increase in tolerance under $\mathrm{Cd}$ stress as compared to other traditionally used wheat cultivars [87].

We believe that conventional breeding methods have had partial success in the development of low-Cd wheat. However, with these breeding methods, breeders can only select low-Cd wheat cultivars. So far, there is no breeding strategy that has been developed for the enhancement of the $\mathrm{Cd}$-resistant potential in wheat. The main obstacle for $\mathrm{Cd}$ breeding in wheat is the low magnitude of genetic variation. Conventional breeding practices need to create genetic variations among wheat cultivars. Once the variation is there, it provides an opportunity to select the desired genotypes-those that have an absolute expression of specific characters. Hence, conventional breeding methods typically require a tedious effort, while the complexity of the wheat genome and the time-consuming selection process inhibit the identification of low-Cd cultivars.

\subsection{Marker-Quantitative Trait Loci (QTL) Analysis for Cd Toxicity in Wheat}

With the advances in the production of cost-effective genome wide molecular markers, quantitative trait loci (QTL) analysis has been frequently addressed for wheat genetic mapping of $\mathrm{Cd}$ toxicity. In the last decades, numerous studies have been performed to identify Cd-associated QTL determining Cd uptake and stress in wheat plants. Different categories of molecular markers were used for tagging the marker-QTL of Cd resistance in wheat (Table 2). A major QTL (designated QCdu.ndsu-5B) of Cd uptake on chromosome arm 5BL within a $0.3 \mathrm{cM}$ distance in durum wheat was identified with SNP markers [77]. Similarly, Penner et al (1995) detected a dominant random amplified polymorphic DNA (RAPD) marker (OPC-20) for low Cd uptake in western Canadian durum wheat [88]. An SNP marker (IWA1775) on chromosome 5BL was found to be associated with grain Cd content in durum wheat cultivars [89]. The associated QTL explained $54.3 \%$ of phenotypic variation, and it was further was converted to the user-friendly KASPar assay in order to discern Cd-resistant lines. Moreover, a major locus (Cdu1) on chromosome 5B conferring low grain Cd in durum wheat was mapped with an SSR marker [90]. This locus was found to be collinear with rice and Brachypodium distachyon through newly developed ESM markers using recombinant substitution lines (RSLs) [91].

The availability of adequately dense molecular markers in the wheat genome has been the main limitation in the identification of Cd-associated QTL. However, high-throughput genome sequencing technologies have begun to overcome this obstacle. The advent of multiplexed sequencing technology has enhanced the identification of closely linked QTL as well markers within genes/QTL controlling wheat $\mathrm{Cd}$ toxicity metabolism. In this regard, the high-quality reference sequence of wheat can be used as a genomic resource to accelerate wheat $\mathrm{Cd}$ research and breeding. Future studies may focus on the exploration of Cd-associated QTLs, paving the way for routine pyramiding [92], multiline [93], and mixture strategies to breed low-Cd wheat cultivars with the desired traits. 
Table 1. Phenotypic evaluation of wheat cultivars under Cd stress.

\begin{tabular}{|c|c|c|c|c|c|c|c|}
\hline Culture Conditions & $\begin{array}{c}\text { Number of } \\
\text { Cultivars Tested }\end{array}$ & Treatments & Toxicological Indicators & Cd Concentrations in Traits (Average) $\left(\mathrm{mg} \mathrm{kg}^{-1}\right.$ ) & $\begin{array}{c}\text { Tolerant and } \\
\text { Low-Metal Cultivars }\end{array}$ & $\begin{array}{c}\text { High } \\
\text { Accumulators }\end{array}$ & Reference \\
\hline Hydroponic culture & 15 & $\begin{array}{l}0,15,30 \text {, and } 45 \mu \mathrm{M} \text { for } \\
2 \text { weeks }\end{array}$ & $\begin{array}{l}\text { Biomass } \mathrm{Cd} \text { at seedling } \\
\text { stage }\end{array}$ & 51-67 (60) (shoot $\mathrm{Cd}$ at $15 \mathrm{mM}$ treatment) & $\begin{array}{l}\text { Lasani-2008 and } \\
\text { Iqbal-2000 }\end{array}$ & $\begin{array}{l}\text { Sehar-2006 and } \\
\text { Inqlab-91 }\end{array}$ & [82] \\
\hline Field pot culture & 51 & $20 \mathrm{mg} / \mathrm{kg}$ for life cycle & Grain Cd & $1.09-6.15(3.5)$ & Ilirija & 10 & [31] \\
\hline Hydroponic culture & 10 & $2 \mathrm{nM}$ for life cycle & $\begin{array}{l}\text { Biomass and } \mathrm{Cd} \text { among } \\
\text { organs }\end{array}$ & $0.03-0.08 \mu \mathrm{g} / \mathrm{g}$ (grain) & Strongfield & Dakter & [94] \\
\hline Field survey & 59 & $0.107-2.292 \mathrm{mg} / \mathrm{kg}$ & Grain Cd & $0.005-0.150$ & $\begin{array}{l}\text { Jimai518, Heng0628, } \\
\text { Heng09, and Guan29 }\end{array}$ & - & [95] \\
\hline Hydroponic culture & 16 & $1 \mu \mathrm{mol} / \mathrm{L}$ for 7 weeks & $\begin{array}{l}\text { Growth parameters and } \\
\text { biomass } C d\end{array}$ & 32.2-63.0 (48.1) (based on shoot dry weight) & E81513 & - & [96] \\
\hline Field trial & 20 & Around $10.5 \mathrm{mg} / \mathrm{kg}$ & Grain Cd & $0.1-0.17$ & Kaimai18 & Zhengmai9405 & [97] \\
\hline Hydroponic culture & 30 & $1 \mathrm{mg} / \mathrm{L}$ for 21 days & Seedling biomass $\mathrm{Cd}$ & $0.91-6.74$ (3.83) (shoot) & $\begin{array}{l}\text { LF-13, LF-16, and LF-21 } \\
\text { (both root and shoot) }\end{array}$ & LF-1 & [98] \\
\hline Hydroponic culture & 2 & $\begin{array}{l}0,6,30,75, \text { and } 150 \mu \mathrm{M} \\
\text { for } 15 \text { days }\end{array}$ & $\begin{array}{l}\text { Root, shoot, and leaf traits } \\
\text { under Cd }\end{array}$ & $\begin{array}{l}\text { For BALCALI- } 85 \text { shoot } C d \text { on average was } 135 \text {, and } \\
\text { root Cd was } 3371 \text {, for C1252 shoot Cd was } 162 \text { and } \\
\text { root Cd was } 1556\end{array}$ & C-1252 & - & [99] \\
\hline Hydroponic culture & 40 & $0.5 \mathrm{mM}$ & $\begin{array}{l}\text { Roots, flag leaf, grain, and } \\
\text { grain coats under } C d\end{array}$ & $\begin{array}{c}\text { Cd in root on average was 29.1, in flag leaf it was 8.4, } \\
\text { and in grains it was } 2.6\end{array}$ & - & $\begin{array}{c}\text { Mjolner, } \\
\text { Rental, Tjalve, } \\
\text { Hanno, } \\
\text { Grandur, and } \\
\text { Extradur }\end{array}$ & [100] \\
\hline $\begin{array}{l}\text { Sand was used in } \\
\text { thermophore plates }\end{array}$ & 4 & $0,5,20,50$, and $80 \mathrm{mg} / \mathrm{L}$ & $\begin{array}{l}\text { Seed germination and } \\
\text { seedling growth }\end{array}$ & $\begin{array}{c}\text { Seed germination } 68.8 \% \text {, germination index } 6.4 \% \text {, } \\
\text { germination energy } 60 \% \text {, and mean germination } \\
\text { time } 5.1 \text { days }\end{array}$ & Sehar-06 & - & [101] \\
\hline Hydroponic culture & 3 & $200 \mu \mathrm{mol} / \mathrm{L}$ for 8 days & Root and leaf $\mathrm{Cd}$ & 0.125 for 4 days and 0.14 for 8 days & CM42 and CM47 & CY12 & [102] \\
\hline Hydroponic solution & 2 & $\begin{array}{l}150 \mu \mathrm{M}, 200 \mu \mathrm{M} \text {, and } \\
250 \mu \mathrm{M} \text { for } 36 \text { days }\end{array}$ & $\begin{array}{l}\text { Seed germination and } \\
\text { seedling growth }\end{array}$ & $\begin{array}{l}\text { On average, } 20.1 \% \text { reduction was observed in } \\
\text { NARC- } 11 \text { and } 23 \% \text { in Galaxy }\end{array}$ & NARC-11 & - & [103] \\
\hline Greenhouse experiment & 5 & $\begin{array}{l}0,25,50, \text { and } 100 \mathrm{mg} \\
\mathrm{Cd} / \mathrm{kg}\end{array}$ & $\begin{array}{l}\text { Photosynthesis and yield } \\
\text { characteristics }\end{array}$ & $\begin{array}{c}\text { Average } \mathrm{Cd} \text { for shoot length was } 30 \text {, shoot dry } \\
\text { weight } 221 \text {, leaf area } 29.6, \text { and the net } \\
\text { photosynthesis rate was } 12.7(\mathrm{mg} \mathrm{Cd} / \mathrm{kg})\end{array}$ & PBW343 & - & [104] \\
\hline Hydroponic culture & 3 & 0,2 , and $4 \mu \mathrm{M}$ & Cd root morphology & $\begin{array}{c}\text { Cd for shoot dry weight was } 0.27 \text { g plant- } 1 \text {, root dry } \\
\text { weight was } 0.14 \text { g plant- } 1 \text {, root tip was } 941 \text {, and total } \\
\text { root length was } 694 \mathrm{~cm}\end{array}$ & Bakhtawar-92 & - & [105] \\
\hline Hydroponic culture & 5 & $1 \mathrm{mg}$ & $\begin{array}{l}\text { Biomass production, yield, } \\
\text { and yield components of } \\
\text { wheat }\end{array}$ & $\begin{array}{l}\text { Average } \mathrm{Cd} \text { is root was } 601.4 \text {, in shoot } 27.8 \text {, and in } \\
\text { grains } 3.6 \mathrm{mg} / \mathrm{kg}\end{array}$ & Li 667 and Ailuyuang & - & [106] \\
\hline Hydroponic culture & 24 & $50 \mu \mathrm{M}$ for 24 days & $\begin{array}{l}\text { Root and shoot parameters } \\
\text { under } \mathrm{Cd}\end{array}$ & $\begin{array}{l}\text { Average } C d \text { for shoot } C d \text { concentration was } 104.0 \\
\text { shoot } C d \text { concentration was } 1773 \text {, and total } C d \\
\text { accumulation was } 0.055\end{array}$ & $\begin{array}{l}\text { B and D genomes } \\
\text { cultivars showed } \\
\text { tolerance }\end{array}$ & $\begin{array}{c}\mathrm{R} \text { genome } \\
\text { wheat cultivars }\end{array}$ & [107] \\
\hline Hydroponic culture & 3 & $\begin{array}{c}0,0.1,0.5,1.0, \text { and } 2.0 \\
\mu \mathrm{M}\end{array}$ & $\begin{array}{l}\text { Shoot and root biomass, } \\
\text { root length, and leaf area } \\
\text { Cd effect on wheat growth, }\end{array}$ & $\begin{array}{l}\text { Concentrations higher than } 0.1(\text { imole/ } / \mathrm{L}) \\
\text { significantly decreased the traits' performances } \\
\text { Average } \mathrm{Cd} \text { shoot dry weight under } 6 \mathrm{Cd}\end{array}$ & Kyle and SC84-994 & - & [85] \\
\hline Hydroponic culture & 3 & $\begin{array}{l}0,10,20,30,40, \text { and } 50 \\
\mu \mathrm{M} \text { for } 24 \text { days }\end{array}$ & $\begin{array}{l}\text { leaf photon energy } \\
\text { conversion, gas exchange, } \\
\text { and Cd accumulation }\end{array}$ & $\begin{array}{l}\text { concentration was } 0.27 \mathrm{~g} / \mathrm{plant} \text {, root dry weight } 0.08 \\
\mathrm{~g} / \text { plant, shoot height } 20.9 \mathrm{~cm} \text {, tiller number } 3.1 \text { per } \\
\text { plant, and secondary root number } 15.6 \text { per plant }\end{array}$ & Jing 411 and Yangmai 10 & - & [108] \\
\hline
\end{tabular}


Table 2. Marker genotype and quantitative trait loci (QTL) analysis for low $\mathrm{Cd}$ in wheat.

\begin{tabular}{|c|c|c|c|c|c|}
\hline Wheat Germplasm & Traits Investigated & Marker & Associated Marker/QTL & Breeding Technique & References \\
\hline 103 RIL population & $\begin{array}{l}13 \text { traits of germination, } \\
\text { growth, and physiology and } 6 \\
\text { other traits were investigated } \\
\text { for } \mathrm{Cd} \text { tolerance and } \\
\text { accumulation }\end{array}$ & $\begin{array}{l}\text { A linkage map was used, } \\
\text { constructed using } \\
\text { different markers }\end{array}$ & 26 QTL & $\begin{array}{l}\text { Marker-assisted selection } \\
\text { (MAS) }\end{array}$ & [109] \\
\hline $\begin{array}{l}190 \text { RIL mapping } \\
\text { population }\end{array}$ & Grain Cd content & $90 \mathrm{~K}$ wheat SNP arrays & A single major QTL & $\begin{array}{l}\text { Inclusive composite interval } \\
\text { mapping (ICIM) method }\end{array}$ & [77] \\
\hline 167 RILs & Cd level & 90K wheat SNP arrays & A single putative QTL & Composite interval mapping & [89] \\
\hline $\begin{array}{c}70 \text { F8 lines developed by } \\
\text { the single-seed descent } \\
\text { method }\end{array}$ & - & $\begin{array}{l}\text { Random amplified } \\
\text { polymorphic DNA } \\
\text { (RAPD) markers }\end{array}$ & 2 RAPD markers were found to be associated & MAS & [88] \\
\hline $155 \mathrm{DH}$ lines & Grain Cd concentration & SSR markers & Cdu1 locus & MAS & [90] \\
\hline $\begin{array}{l}155 \text { recombinant } \\
\text { substitution lines }\end{array}$ & Grain Cd concentration & $\begin{array}{l}\text { PCR-based markers were } \\
\text { developed for ESTs }\end{array}$ & $\begin{array}{l}2 \text { ESM markers, } 1 \text { STS, and } 1 \text { minor QTL for } \\
\text { grain Cd content were detected }\end{array}$ & MAS & [91] \\
\hline $\begin{array}{l}155 \text { recombinant } \\
\text { substitution lines }\end{array}$ & Cd concentration & ESTs and STS markers & $\begin{array}{l}2 \text { ESMs and } 5 \text { STS markers were identified } \\
\text { that co-segregated with Cdu-B1 }\end{array}$ & MAS & [110] \\
\hline $\begin{array}{l}\text { Total of } 4178 \text { advance, } \\
\text { elite and, uniform } \\
\text { regional durum nurseries } \\
\text { were used }\end{array}$ & Grain Cd content & SNP markers & $\begin{array}{l}3 \text { markers on chromosome } 5 \mathrm{~B} \text { were found to } \\
\text { be linked; } 1 \text { marker with } \mathrm{Cd} \text { was } \\
\text { polymorphic while the other } 2 \text { were not } \\
\text { polymorphic in all of the population }\end{array}$ & MAB & [111] \\
\hline 14 wheat cultivars & Cd concentration & AFLP and RAPD markers & $\begin{array}{l}113 \text { AFLP and } 77 \text { RAPD markers were found } \\
\text { to be associated }\end{array}$ & MAS & [112] \\
\hline 2 durum wheat lines & $\mathrm{Cd}$ in grains & SNPs & $\begin{array}{l}1 \text { QTL on chromosome 2B with 3\% } \\
\text { phenotypic variations and } 1 \text { SNP marker on } \\
\text { chromosome } 5 \text { B explaining } 34 \% \text { of the } \\
\text { phenotypic variation were detected }\end{array}$ & Association mapping analysis & [113] \\
\hline
\end{tabular}




\section{Conclusions}

$\mathrm{Cd}$ is one of the most prevalent toxins in the environment worldwide. Its existence within soil has been acknowledged as a serious hazard to agricultural production. The excessive amount of $\mathrm{Cd}$ in the environment has had adverse effects on wheat growth and development. Conventional and molecular breeding strategies in wheat have been devised to minimize Cd uptake and toxicity. The potential of conventional breeding is still an attractive approach to change the $\mathrm{Cd}$ profile of wheat cultivars, if this is perceived as a priority. Molecular markers are powerful in the selection of wheat varieties with low $\mathrm{Cd}$ and other desired traits $[114,115]$. The manipulation of heterosis also presents new perspectives for improving wheat $\mathrm{Cd}$ potential and adaptation to $\mathrm{Cd}$ stresses. However, there remain several constraints to breeding low-Cd wheat cultivars, as it is time-consuming and the process of genetic enhancement is slow.

Modern breeding tools also lend great potential to plant breeding programs to be used along with conventional breeding for the development of low-Cd cultivars. Candidate gene and QTL identification through GWAS analysis could accelerate wheat $\mathrm{Cd}$ breeding programs. While genome editing tools are mature [116], molecular breeding for wheat with the desired traits is becoming a reality. Future studies may focus more on the tagging of these candidate genes with markers as well as on pyramiding these genes through MAS.

Author Contributions: X.L. initiated the concept. All authors contributed to the writing and approved the submitted version.

Funding: This research was funded by the CAS President's International Fellowship Initiative (PIFI) fund (2018PB0084), the National Key Research and Development Program (2018YFD0800306), and the Hebei Science Fund for Distinguished Young Scholars (D2018503005).

Conflicts of Interest: The authors declare no conflict of interest.

\section{References}

1. Tolcin, A.C. Mineral resource of the month: Zinc. Earth 2009, 54, 29.

2. Lu, C.; Tian, H. Global nitrogen and phosphorus fertilizer use for agriculture production in the past half century: Shifted hot spots and nutrient imbalance. Earth Syst. Sci. Data 2017, 9, 1-33. [CrossRef]

3. Nziguheba, G.; Smolders, E. Inputs of trace elements in agricultural soils via phosphate fertilizers in European countries. Sci. Total Environ. 2008, 390, 53-57. [CrossRef] [PubMed]

4. Mortvedt, J.J. Cadmium Levels in Soils and Plants from Some Long-term Soil Fertility Experiments in the United States of America. J. Environ. Qual. 1987, 16, 137-142. [CrossRef]

5. Zhang, X.; Zhong, T.; Liu, L.; Ouyang, X. Impact of Soil Heavy Metal Pollution on Food Safety in China. PLoS ONE 2015, 10, e0135182. [CrossRef] [PubMed]

6. Jing, R.L.; Chang, X.P. Genetic diversity in wheat (T. aestivum) germplasm resources with drought resistance. Acta Bot. Boreal.-Occident. Sin. 2003, 23, 410.

7. Wu, R. The Pollution Status and Health Risk Assessment of Heavy Metals from the Sewage-Irrigated Wheat and Corn in Shijiazhuang; Hebei Medical University: Shijiazhuang, China, 2015.

8. Han, J.; Ma, J. Polluting, transferring and accumulating of heavy metals in soil-wheat system in sewage irrigation region: A case study in Huafei River in Kaifeng, Guangdong. Ecol. Environ. 2004, 13, 578-580.

9. Yang, J.; Cheng, T.; Zheng, Y.; Luo, J.; Liu, H.; Wu, W.; Chen, Y. Dynamic of heavy metals in wheat grains collected from the Liangfeng Irrigated Area, Beijing and a discussion of availability and human health risks. Acta Sci. Circumst. 2005, 25, 1661-1668.

10. Zhang, X. Risk Assessment of Heavy Metal Toxicity through Wheat and Rice Grow in Tianjin Sewage Irrigated Area; Tianjin Normal Univesity: Tianjin, China, 2014.

11. Nordberg, G.F. Historical perspectives on cadmium toxicology. Toxicol. Appl. Pharmacol. 2009, 238, 192-200. [CrossRef] [PubMed]

12. Oliver, D.P.; Gartrell, J.W.; Tiller, K.G.; Correll, R.; Cozens, G.D.; Youngberg, B.L. Differential responses of Australian wheat cultivars to cadmium concentration in wheat grain. Aust. J. Agric. Res. 1995, 46, 873-886. [CrossRef] 
13. Yu, H.; Wang, J.; Fang, W.; Yuan, J.; Yang, Z. Cadmium accumulation in different rice cultivars and screening for pollution-safe cultivars of rice. Sci. Total Environ. 2006, 370, 302-309. [CrossRef] [PubMed]

14. Grant, C.A.; Clarke, J.M.; Duguid, S.; Chaney, R.L. Selection and breeding of plant cultivars to minimize cadmium accumulation. Sci. Total Environ. 2008, 390, 301-310. [CrossRef] [PubMed]

15. Ashrafzadeh, S.; Leung, D.W.M. Development of Cadmium-Safe Crop Cultivars: A Mini Review. J. Crop Improv. 2016, 30, 107-117. [CrossRef]

16. Siedlecka, A. Some aspects of interactions between heavy metals and plant mineral nutrients. Acta Soc. Bot. Pol. 1995, 64, 265-272. [CrossRef]

17. Benavides, M.P.; Gallego, S.M.; Tomaro, M.L. Cadmium toxicity in plants. Braz. J. Plant Physiol. 2005, 17, 21-34. [CrossRef]

18. Grant, C.; Buckley, W.; Bailey, L.D.; Selles, F. Cadmium accumulation in crops. Can. J. Plant Sci. 1998, 78, 1-17. [CrossRef]

19. Irfan, M.; Hayat, S.; Ahmad, A.; Alyemeni, M.N. Soil cadmium enrichment: Allocation and plant physiological manifestations. Saudi J. Biol. Sci. 2013, 20, 1-10. [CrossRef] [PubMed]

20. Maksymiec, W.; Krupa, Z. The effects of short-term exposition to Cd, excess Cu ions and jasmonate on oxidative stress appearing in Arabidopsis thaliana. Environ. Exp. Bot. 2006, 57, 187-194. [CrossRef]

21. Lin, R.; Wang, X.; Luo, Y.; Du, W.; Guo, H.; Yin, D. Effects of soil cadmium on growth, oxidative stress and antioxidant system in wheat seedlings (Triticum aestivum L.). Chemosphere 2007, 69, 89-98. [CrossRef] [PubMed]

22. Sgherri, C.; Quartacci, M.F.; Izzo, R.; Navari-Izzo, F. Relation between lipoic acid and cell redox status in wheat grown in excess copper. Plant Physiol. Biochem. 2002, 40, 591-597. [CrossRef]

23. Lesser, M.P. Oxidative stress in marine environments: Biochemistry and physiological ecology. Annu. Rev. Physiol. 2006, 68, 253-278. [CrossRef] [PubMed]

24. Chugh, L.K.; Sawhney, S.K. Photosynthetic activities of Pisum sativum seedlings grown in presence of cadmium. Plant Physiol. Biochem. 1999, 37, 297-303. [CrossRef]

25. Costa, G.; Spitz, E. Influence of cadmium on soluble carbohydrates, free amino acids, protein content of in vitro cultured Lupinus albus. Plant Sci. 1997, 128, 131-140. [CrossRef]

26. Rizwan, M.; Meunier, J.-D.; Davidian, J.-C.; Pokrovsky, O.; Bovet, N.; Keller, C. Silicon alleviates Cd stress of wheat seedlings (Triticum turgidum L. cv. Claudio) grown in hydroponics. Environ. Sci. Pollut. Res. 2016, 23, $1414-1427$. [CrossRef] [PubMed]

27. Khan, N.; Singh, S.; Nazar, R. Activities of antioxidative enzymes, sulphur assimilation, photosynthetic activity and growth of wheat (Triticum aestivum) cultivars differing in yield potential under cadmium stress. J. Agron. Crop Sci. 2007, 193, 435-444. [CrossRef]

28. Di Toppi, L.S.; Gabbrielli, R. Response to cadmium in higher plants. Environ. Exp. Bot. 1999, 41, $105-130$. [CrossRef]

29. Black, A.; McLaren, R.G.; Speir, T.W.; Clucas, L.; Condron, L.M. Gradient differences in soil metal solubility and uptake by shoots and roots of wheat (T. aestivum). Biol. Fertil. Soils 2014, 50, 685-694. [CrossRef]

30. Atal, N.; Saradhi, P.P.; Mohanty, P. Inhibition of the chloroplast photochemical reactions by treatment of wheat seedlings with low concentrations of cadmium: Analysis of electron transport activities and changes in fluorescence yield. Plant Cell Physiol. 1991, 32, 943-951. [CrossRef]

31. Rebekić, A.; Lončarić, Z. Genotypic difference in cadmium effect on agronomic traits and grain zinc and iron concentration in winter wheat. Emir. J. Food Agric. 2016, 28, 772-778. [CrossRef]

32. Ci, D.; Jiang, D.; Dai, T.; Jing, Q.; Cao, W. Effects of cadmium on plant growth and physiological traits in contrast wheat recombinant inbred lines differing in cadmium tolerance. Chemosphere 2009, 77, 1620-1625. [CrossRef] [PubMed]

33. Stolt, J.; Oscarson, P. Influence of cadmium on net nitrate uptake kinetics in wheat. J. Plant Nutr. 2002, 25, $2763-2774$. [CrossRef]

34. Mohamed, A.A.; Castagna, A.; Ranieri, A.; Sanita di Toppi, L. Cadmium tolerance in Brassica juncea roots and shoots is affected by antioxidant status and phytochelatin biosynthesis. Plant Physiol. Biochem. 2012, 57, 15-22. [CrossRef] [PubMed]

35. Cuypers, A.; Smeets, K.; Ruytinx, J.; Opdenakker, K.; Keunen, E.; Remans, T.; Horemans, N.; Vanhoudt, N.; Van Sanden, S.; Van Belleghem, F.; et al. The cellular redox state as a modulator in cadmium and copper responses in Arabidopsis thaliana seedlings. J. Plant Physiol. 2011, 168, 309-316. [CrossRef] [PubMed] 
36. Sharma, S.S.; Dietz, K.J. The relationship between metal toxicity and cellular redox imbalance. Trends Plant Sci. 2009, 14, 43-50. [CrossRef] [PubMed]

37. Yannarelli, G.G.; Fernandez-Alvarez, A.J.; Santa-Cruz, D.M.; Tomaro, M.L. Glutathione reductase activity and isoforms in leaves and roots of wheat plants subjected to cadmium stress. Phytochemistry 2007, 68, 505-512. [CrossRef] [PubMed]

38. Ishikawa, T.; Li, Z.S.; Lu, Y.P.; Rea, P.A. The GS-X pump in plant, yeast, and animal cells: Structure, function, and gene expression. Biosci. Rep. 1997, 17, 189-207. [CrossRef] [PubMed]

39. Martinoia, E.; Klein, M.; Geisler, M.; Bovet, L.; Forestier, C.; Kolukisaoglu, U.; Muller-Rober, B.; Schulz, B. Multifunctionality of plant ABC transporters-More than just detoxifiers. Planta 2002, 214, 345-355. [CrossRef] [PubMed]

40. Tommasini, R.; Vogt, E.; Fromenteau, M.; Hortensteiner, S.; Matile, P.; Amrhein, N.; Martinoia, E. An ABC-transporter of Arabidopsis thaliana has both glutathione-conjugate and chlorophyll catabolite transport activity. Plant J. 1998, 13, 773-780. [CrossRef] [PubMed]

41. Bhati, K.K.; Alok, A.; Kumar, A.; Kaur, J.; Tiwari, S.; Pandey, A.K. Silencing of ABCC13 transporter in wheat reveals its involvement in grain development, phytic acid accumulation and lateral root formation. J. Exp. Bot. 2016, 67, 4379-4389. [CrossRef] [PubMed]

42. Bhati, K.K.; Aggarwal, S.; Sharma, S.; Mantri, S.; Singh, S.P.; Bhalla, S.; Kaur, J.; Tiwari, S.; Roy, J.K.; Tuli, R.; et al. Differential expression of structural genes for the late phase of phytic acid biosynthesis in developing seeds of wheat (Triticum aestivum L.). Plant Sci. 2014, 224, 74-85. [CrossRef] [PubMed]

43. Bhati, K.K.; Sharma, S.; Aggarwal, S.; Kaur, M.; Shukla, V.; Kaur, J.; Mantri, S.; Pandey, A.K. Genome-wide identification and expression characterization of ABCC-MRP transporters in hexaploid wheat. Front. Plant Sci. 2015, 6, 488. [CrossRef] [PubMed]

44. Grill, E.; Loffler, S.; Winnacker, E.L.; Zenk, M.H. Phytochelatins, the heavy-metal-binding peptides of plants, are synthesized from glutathione by a specific gamma-glutamylcysteine dipeptidyl transpeptidase (phytochelatin synthase). Proc. Natl. Acad. Sci. USA 1989, 86, 6838-6842. [CrossRef] [PubMed]

45. Ha, S.B.; Smith, A.P.; Howden, R.; Dietrich, W.M.; Bugg, S.; O'Connell, M.J.; Goldsbrough, P.B.; Cobbett, C.S. Phytochelatin synthase genes from Arabidopsis and the yeast Schizosaccharomyces pombe. Plant Cell 1999, 11, 1153-1164. [CrossRef] [PubMed]

46. Ranieri, A.; Castagna, A.; Scebba, F.; Careri, M.; Zagnoni, I.; Predieri, G.; Pagliari, M.; di Toppi, L.S. Oxidative stress and phytochelatin characterisation in bread wheat exposed to cadmium excess. Plant Physiol. Biochem. 2005, 43, 45-54. [CrossRef] [PubMed]

47. Salt, D.E.; Rauser, W.E. MgATP-Dependent Transport of Phytochelatins Across the Tonoplast of Oat Roots. Plant Physiol. 1995, 107, 1293-1301. [CrossRef] [PubMed]

48. Gong, J.M.; Lee, D.A.; Schroeder, J.I. Long-distance root-to-shoot transport of phytochelatins and cadmium in Arabidopsis. Proc. Natl. Acad. Sci. USA 2003, 100, 10118-10123. [CrossRef] [PubMed]

49. Lee, S.; Moon, J.S.; Ko, T.S.; Petros, D.; Goldsbrough, P.B.; Korban, S.S. Overexpression of Arabidopsis phytochelatin synthase paradoxically leads to hypersensitivity to cadmium stress. Plant Physiol. 2003, 131, 656-663. [CrossRef] [PubMed]

50. Wojas, S.; Clemens, S.; Hennig, J.; Sklodowska, A.; Kopera, E.; Schat, H.; Bal, W.; Antosiewicz, D.M. Overexpression of phytochelatin synthase in tobacco: Distinctive effects of AtPCS1 and CePCS genes on plant response to cadmium. J. Exp. Bot. 2008, 59, 2205-2219. [CrossRef] [PubMed]

51. Li, Y.; Dhankher, O.P.; Carreira, L.; Lee, D.; Chen, A.; Schroeder, J.I.; Balish, R.S.; Meagher, R.B. Overexpression of phytochelatin synthase in Arabidopsis leads to enhanced arsenic tolerance and cadmium hypersensitivity. Plant Cell Physiol. 2004, 45, 1787-1797. [CrossRef] [PubMed]

52. Wang, F.; Wang, Z.; Zhu, C. Heteroexpression of the wheat phytochelatin synthase gene (TaPCS1) in rice enhances cadmium sensitivity. Acta Biochim. Biophys. Sin. 2012, 44, 886-893. [CrossRef] [PubMed]

53. Brini, F.; Gaxiola, R.A.; Berkowitz, G.A.; Masmoudi, K. Cloning and characterization of a wheat vacuolar cation/proton antiporter and pyrophosphatase proton pump. Plant Physiol. Biochem. 2005, 43, 347-354. [CrossRef] [PubMed]

54. Khoudi, H.; Maatar, Y.; Gouiaa, S.; Masmoudi, K. Transgenic tobacco plants expressing ectopically wheat $\mathrm{H}(+)$-pyrophosphatase $(\mathrm{H}(+)$-PPase) gene TaVP1 show enhanced accumulation and tolerance to cadmium. J. Plant Physiol. 2012, 169, 98-103. [CrossRef] [PubMed] 
55. Kim, Y.Y.; Kim, D.Y.; Shim, D.; Song, W.Y.; Lee, J.; Schroeder, J.I.; Kim, S.; Moran, N.; Lee, Y. Expression of the novel wheat gene TM20 confers enhanced cadmium tolerance to bakers' yeast. J. Biol. Chem. 2008, 283, 15893-15902. [CrossRef] [PubMed]

56. Tran, T.A.; Popova, L.P. Functions and toxicity of cadmium in plants: Recent advances and future prospects. Turk. J. Bot. 2013, 37, 1-13. [CrossRef]

57. Wang, Z.; Li, Q.; Wu, W.; Guo, J.; Yang, Y. Cadmium stress tolerance in wheat seedlings induced by ascorbic acid was mediated by NO signaling pathways. Ecotoxicol. Environ. Saf. 2017, 135, 75-81. [CrossRef] [PubMed]

58. Metwally, A.; Finkemeier, I.; Georgi, M.; Dietz, K.J. Salicylic acid alleviates the cadmium toxicity in barley seedlings. Plant Physiol. 2003, 132, 272-281. [CrossRef] [PubMed]

59. Krantev, A.; Yordanova, R.; Janda, T.; Szalai, G.; Popova, L. Treatment with salicylic acid decreases the effect of cadmium on photosynthesis in maize plants. J. Plant Physiol. 2008, 165, 920-931. [CrossRef] [PubMed]

60. Kovacs, V.; Gondor, O.K.; Szalai, G.; Darko, E.; Majlath, I.; Janda, T.; Pal, M. Synthesis and role of salicylic acid in wheat varieties with different levels of cadmium tolerance. J. Hazard. Mater. 2014, 280, 12-19. [CrossRef] [PubMed]

61. Wu, H.; Chen, C.; Du, J.; Liu, H.; Cui, Y.; Zhang, Y.; He, Y.; Wang, Y.; Chu, C.; Feng, Z.; et al. Co-overexpression FIT with AtbHLH38 or AtbHLH39 in Arabidopsis-enhanced cadmium tolerance via increased cadmium sequestration in roots and improved iron homeostasis of shoots. Plant Physiol. 2012, 158, 790-800. [CrossRef] [PubMed]

62. Huang, C.; Zhou, J.; Jie, Y.; Xing, H.; Zhong, Y.; Yu, W.; She, W.; Ma, Y.; Liu, Z.; Zhang, Y. A Ramie bZIP Transcription Factor BnbZIP2 Is Involved in Drought, Salt, and Heavy Metal Stress Response. DNA Cell Biol. 2016, 35, 776-786. [CrossRef] [PubMed]

63. Chen, J.; Yang, L.; Yan, X.; Liu, Y.; Wang, R.; Fan, T.; Ren, Y.; Tang, X.; Xiao, F.; Liu, Y.; et al. Zinc-Finger Transcription Factor ZAT6 Positively Regulates Cadmium Tolerance through the Glutathione-Dependent Pathway in Arabidopsis. Plant Physiol. 2016, 171, 707-719. [CrossRef] [PubMed]

64. Lin, T.; Yang, W.; Lu, W.; Wang, Y.; Qi, X. Transcription Factors PvERF15 and PvMTF-1 Form a Cadmium Stress Transcriptional Pathway. Plant Physiol. 2017, 173, 1565-1573. [CrossRef] [PubMed]

65. Shim, D.; Hwang, J.-U.; Lee, J.; Lee, S.; Choi, Y.; An, G.; Martinoia, E.; Lee, Y. Orthologs of the class A4 heat shock transcription factor HsfA4a confer cadmium tolerance in wheat and rice. Plant Cell 2009, 21, 4031-4043. [CrossRef] [PubMed]

66. Dobrikova, A.G.; Yotsova, E.K.; Borner, A.; Landjeva, S.P.; Apostolova, E.L. The wheat mutant DELLA-encoding gene (Rht-B1c) affects plant photosynthetic responses to cadmium stress. Plant Physiol. Biochem. 2017, 114, 10-18. [CrossRef] [PubMed]

67. Wen, W.; Deng, Q.; Jia, H.; Wei, L.; Wei, J.; Wan, H.; Yang, L.; Cao, W.; Ma, Z. Sequence variations of the partially dominant DELLA gene Rht-B1c in wheat and their functional impacts. J. Exp. Bot. 2013, 64, 3299-3312. [CrossRef] [PubMed]

68. Ren, Y.; Chen, Y.; An, J.; Zhao, Z.; Zhang, G.; Wang, Y.; Wang, W. Wheat expansin gene TaEXPA2 is involved in conferring plant tolerance to Cd toxicity. Plant Sci. 2018, 270, 245-256. [CrossRef] [PubMed]

69. Han, Y.; Chen, Y.; Yin, S.; Zhang, M.; Wang, W. Over-expression of TaEXPB23, a wheat expansin gene, improves oxidative stress tolerance in transgenic tobacco plants. J. Plant Physiol. 2015, 173, 62-71. [CrossRef] [PubMed]

70. Mcqueenmason, S.; Cosgrove, D.J. Disruption of Hydrogen-Bonding between Plant-Cell Wall Polymers by Proteins That Induce Wall Extension. Proc. Natl. Acad. Sci. USA 1994, 91, 6574-6578. [CrossRef]

71. Yan, A.; Wu, M.; Yan, L.; Hu, R.; Ali, I.; Gan, Y. AtEXP2 is involved in seed germination and abiotic stress response in Arabidopsis. PLoS ONE 2014, 9, e85208. [CrossRef] [PubMed]

72. Kwon, Y.R.; Lee, H.J.; Kim, K.H.; Hong, S.W.; Lee, S.J.; Lee, H. Ectopic expression of Expansin3 or Expansinbeta1 causes enhanced hormone and salt stress sensitivity in Arabidopsis. Biotechnol. Lett. 2008, 30, 1281-1288. [CrossRef] [PubMed]

73. Tan, J.; Wang, J.; Chai, T.; Zhang, Y.; Feng, S.; Li, Y.; Zhao, H.; Liu, H.; Chai, X. Functional analyses of TaHMA2, a P(1B)-type ATPase in wheat. Plant Biotechnol. J. 2013, 11, 420-431. [CrossRef] [PubMed]

74. Collard, B.C.; Mackill, D.J. Marker-assisted selection: An approach for precision plant breeding in the twenty-first century. Philos. Trans. R. Soc. Lond. B Biol. Sci. 2008, 363, 557-572. [CrossRef] [PubMed] 
75. Savadi, S.; Prasad, P.; Kashyap, P.L.; Bhardwaj, S.C. Molecular breeding technologies and strategies for rust resistance in wheat (Triticum aestivum) for sustained food security. Plant Pathol. 2018, 67, 771-791. [CrossRef]

76. Forster, B.; Till, B.; Ghanim, A.; Huynh, H.; Burstmayr, H.; Caligari, P. Accelerated plant breeding. CAB Rev. 2014, 9, 1-16. [CrossRef]

77. Abbasabadi, A.O.; Kumar, A.; Pirseyedi, S.; Salsman, E.; Dobrydina, M.; Poudel, R.S.; AbuHammad, W.A.; Chao, S.; Faris, J.D.; Elias, E.M. Identification and Validation of a New Source of Low Grain Cadmium Accumulation in Durum Wheat. G3 Genes, Genomes Genet. 2018. [CrossRef]

78. Randhawa, H.S.; Asif, M.; Pozniak, C.; Clarke, J.M.; Graf, R.J.; Fox, S.L.; Humphreys, D.G.; Knox, R.E.; DePauw, R.M.; Singh, A.K. Application of molecular markers to wheat breeding in Canada. Plant Breed. 2013, 132, 458-471. [CrossRef]

79. Zhao, X.; Luo, L.; Cao, Y.; Liu, Y.; Li, Y.; Wu, W.; Lan, Y.; Jiang, Y.; Gao, S.; Zhang, Z. Genome-wide association analysis and QTL mapping reveal the genetic control of cadmium accumulation in maize leaf. BMC Genom. 2018, 19, 91. [CrossRef] [PubMed]

80. Reynolds, M.; Mujeeb-Kazi, A.; Sawkins, M. Prospects for utilising plant-adaptive mechanisms to improve wheat and other crops in drought-and salinity-prone environments. Ann. Appl. Biol. 2005, 146, 239-259. [CrossRef]

81. Yue, J.; Wei, X.; Wang, H. Cadmium tolerant and sensitive wheat lines: Their differences in pollutant accumulation, cell damage, and autophagy. Biol. Plant. 2018, 62, 379-387. [CrossRef]

82. Naeem, A.; Saifullah; Rehman, M.Z.-U.; Akhtar, T.; Ok, Y.S.; Rengel, Z. Genetic Variation in Cadmium Accumulation and Tolerance among Wheat Cultivars at the Seedling Stage. Commun. Soil Sci. Plant Anal. 2016, 47, 554-562. [CrossRef]

83. Clarke, J.M.; Norvell, W.A.; Clarke, F.R.; Buckley, W.T. Concentration of cadmium and other elements in the grain of near-isogenic durum lines. Can. J. Plant Sci. 2002, 82, 27-33. [CrossRef]

84. Guttieri, M.; Frels, K.; Waters, B.M.; El-Basyoni, I.S.; Akhunov, E.; Baenziger, P.S. Genetic Variation for Grain Cadmium in Hard Winter Wheat. In Proceedings of the International Plant and Animal Genome Conference Xxii, San Diego, CA, USA, 11-15 January 2014.

85. Jalil, A.; Selles, F.; Clarke, J.M. Effect of cadmium on growth and the uptake of cadmium and other elements by durum wheat. J. Plant Nutr. 1994, 17, 1839-1858. [CrossRef]

86. Stolt, P.; Asp, H.; Hultin, S. Genetic variation in wheat cadmium accumulation on soils with different cadmium concentrations. J. Agron. Crop Sci. 2010, 192, 201-208. [CrossRef]

87. Jordaan, J.P. Hybrid wheat: Advances and challenges. Increasing Yield Potential Wheat Break. Barriers 1996, 66, 66-67.

88. Penner, G.A.; Bezte, L.J.; Leisle, D.; Clarke, J. Identification of RAPD markers linked to a gene governing cadmium uptake in durum wheat. Genome 1995, 38, 543-547. [CrossRef] [PubMed]

89. AbuHammad, W.A.; Mamidi, S.; Kumar, A.; Pirseyedi, S.; Manthey, F.A.; Kianian, S.F.; Alamri, M.S.; Mergoum, M.; Elias, E.M. Identification and validation of a major cadmium accumulation locus and closely associated SNP markers in North Dakota durum wheat cultivars. Mol. Breed. 2016, 36, 112. [CrossRef]

90. Knox, R.E.; Pozniak, C.J.; Clarke, F.R.; Clarke, J.M.; Houshmand, S.; Singh, A.K. Chromosomal location of the cadmium uptake gene (Cdu1) in durum wheat. Genome Natl. Res. Counc. Can. 2009, 52, 741-747. [CrossRef] [PubMed]

91. Wiebe, K.; Harris, N.S.; Faris, J.D.; Clarke, J.M.; Knox, R.E.; Taylor, G.J.; Pozniak, C.J. Targeted mapping of Cdu1, a major locus regulating grain cadmium concentration in durum wheat (Triticum turgidum L. var durum). Theor. Appl. Genet. 2010, 121, 1047-1058. [CrossRef] [PubMed]

92. Bonman, J.M.; Khush, G.S.; Nelson, R.J. Breeding Rice for Resistance to Pests. Ann. Rev. Phytopathol. 1992, 30, 507-528. [CrossRef]

93. Abe, S. Breeding of a blast resistant multiline variety of rice, Sasanishiki BL. Jpn. Agric. Res. Q. 2014, 38, $149-154$.

94. Perrier, F.; Yan, B.; Candaudap, F.; Pokrovsky, O.S.; Gourdain, E.; Meleard, B.; Bussière, S.; Coriou, C.; Robert, T; Nguyen, C. Variability in grain cadmium concentration among durum wheat cultivars: Impact of aboveground biomass partitioning. Plant Soil 2016, 404, 307-320. [CrossRef]

95. Xiong, Z.; Li, J.-M.; Zhao, H.W.; Ma, Y.-B. Accumulation and translocation of cadmium in different wheat cultivars in farmland. J. Agro-Environ. Sci. 2018, 37, 36-44.

96. Zhang, G.; Fukami, M.; Sekimoto, H. Genotypic differences in effects of cadmium on growth and nutrient compositions in wheat. J. Plant Nutr. 2008, 23, 1337-1350. [CrossRef] 
97. Ji, S.-Q.; Guo, R.; Wang, H.F.; Zhang, D.Q.; Zhao, S.Z.; Xu, L.-C. Estimate of Pollution by Heavy Metals on Wheat in Henan and the Rule of Cadmium Absorption in Wheat. J. Triticeae Crop. 2006, 26, 154-157.

98. Liu, W.; Liang, L.; Zhang, X.; Zhou, Q. Cultivar variations in cadmium and lead accumulation and distribution among 30 wheat (Triticum aestivum L.) cultivars. Environ. Sci. Pollut. Res. 2015, 22, 8432-8441. [CrossRef] [PubMed]

99. Öztürk, L.; Eker, S.; Özkutlu, F.; Çakmak, İ. Effect of cadmium on growth and concentrations of cadmium, ascorbic acid and sulphydryl groups in durum wheat cultivars. Turk. J. Agric. For. 2003, 27, 161-168.

100. Greger, M.; Löfstedt, M. Comparison of Uptake and Distribution of Cadmium in Different Cultivars of Bread and Durum Wheat. Crop Sci. 2004, 44, 501-507. [CrossRef]

101. Ahmad, I.; Akhtar, M.J.; Zahir, Z.A.; Jamil, A. Effect of cadmium on seed germination and seedling growth of four wheat (Triticum aestivum L.) cultivars. Pak. J. Bot. 2012, 44, 1569-1574.

102. Duan, Y.P.; Yuan, S.; Tu, S.H.; Feng, W.Q.; Xu, F.; Zhang, Z.W.; Chen, Y.E.; Wang, X.; Shang, J.; Lin, H.H. Effects of cadmium stress on alternative oxidase and photosystem II in three wheat cultivars. Z. Naturforsch. C J. Biosci. 2010, 65, 87-94. [CrossRef]

103. Idrees, S.; Shabir, S.; Ilyas, N.; Batool, N.; Kanwal, S. Assessment of cadmium on wheat (Triticum aestivum L.) in hydroponics medium. Agrociencia 2015, 49, 917-929.

104. Khan, N.A.; Ahmad, I.; Singh, S.; Nazar, R. Variation in growth, photosynthesis and yield of five wheat cultivars exposed to cadmium stress. World J. Agric. Sci. 2006, 2, 223-226.

105. Shafi, M.; Zhang, G.P.; Bakht, J.; Khan, M.A.; Ejazulislam; Khan, M.D.; Raziuddin. Effect of cadmium and salinity stresses on root morphology of wheat. Pak. J. Bot. 2010, 42, 2747-2754.

106. Zhang, L.; Li, J.M.; Wang, H.X. Physiological and ecological responses of wheat (Triticum aestivm L.) root to cadmium stress. Chin. J. Soil Sci. 2002, 33, 61-65.

107. Ci, D.; Jiang, D.; Wollenweber, B.; Dai, T.; Jing, Q.; Cao, W. Genetic variance in cadmium tolerance and accumulation in wheat materials differing in ploidy and genome at seedling stage. J. Agron. Crop Sci. 2010, 196, 302-310. [CrossRef]

108. Ci, D.; Jiang, D.; Wollenweber, B.; Dai, T.; Jing, Q.; Cao, W. Cadmium stress in wheat seedlings: Growth, cadmium accumulation and photosynthesis. Acta Physiol. Plant. 2010, 32, 365-373. [CrossRef]

109. Ci, D.; Jiang, D.; Li, S.; Wollenweber, B.; Dai, T.; Cao, W. Identification of quantitative trait loci for cadmium tolerance and accumulation in wheat. Acta Physiol. Plant. 2012, 34, 191-202. [CrossRef]

110. Wiebe, K. Molecular Characterization of Cdu-B1, a Major Locus Controlling Cadmium Accumulation in Durum Wheat (Triticum turgidum L. var durum) Grain; University of Saskatchewan: Saskatoon, SK, Canada, 2012.

111. Salsman, E.; Kumar, A.; AbuHammad, W.; Abbasabadi, A.O.; Dobrydina, M.; Chao, S.; Li, X.; Manthey, F.A.; Elias, E.M. Development and validation of molecular markers for grain cadmium in durum wheat. Mol. Breed. 2018, 38, 28. [CrossRef]

112. Rad, B.S.; Shokrpour, M.; Sofalian, O.; Nezhad, S.E.H.; Avanes, A.; Esfandiari, E. Association Analysis of AFLP and RAPD Markers with Cadmium Accumulation in Wheat. J. Crop Breed. 2016, 8, 126-133.

113. Abuhammad, W.; Elias, E.M.; Mamidi, S.; Mergoum, M. Association Mapping of Cadmium Uptake Locus in Durum Wheat Advanced Breeding Lines. In Proceedings of the American Society of Agronomy International Meeting, Tampa, FL, USA, 3-6 November 2013.

114. Arduini, I.; Masoni, A.; Mariotti, M.; Pampana, S.; Ercoli, L. Cadmium uptake and translocation in durum wheat varieties differing in grain-Cd accumulation. Plant Soil Environ. 2014, 60, 43-49. [CrossRef]

115. Vergine, M.; Aprile, A.; Sabella, E.; Genga, A.; Siciliano, M.; Rampino, P.; Lenucci, M.S.; Luvisi, A.; Bellis, L. Cadmium Concentration in Grains of Durum Wheat (Triticum turgidum L. subsp. durum). J. Agric. Food Chem. 2017, 65, 6240-6246. [CrossRef] [PubMed]

116. Shan, Q.W.; Wang, Y.P.; Li, J.; Gao, C.X. Genome editing in rice and wheat using the CRISPR/Cas system. Nat. Protoc. 2014, 9, 2395-2410. [CrossRef] [PubMed]

(C) 2018 by the authors. Licensee MDPI, Basel, Switzerland. This article is an open access article distributed under the terms and conditions of the Creative Commons Attribution (CC BY) license (http://creativecommons.org/licenses/by/4.0/). 